thigh was quite easy. About two years before the date of her coming to the hospital the little bodies above described first appeared ; they troubled her much by. "milking"-they burst and a discharge like watered milk oozed from them and wetted her dress.

\section{CHILDREN'S INFIRMARY, LIVERPOOL.}

CASE OF SCARLET FEVER WITH PURPURA.

(Under the care of Mr. R. W. MurraY.)

WITH regard to the following case Mr. G. E. Clemons, senior house surgeon (to whom we are also indebted for the notes), writes:--Beyond a passing reference in Fagge nothing is said in the ordinary English text-books on the subject of purpura after scarlet fever. Eustace Smith, Ashby and Wright, Collie and others are silent on the subject. Henoch, ${ }^{1}$ nowever, mentions the manifestation of a hæmorrhagic diathesis as a sequela of scarlet fever, but of eight cases all began in the third or fourth week after the eruption and all terminated favourably. In discussing the etiology of purpura fulminans, ${ }^{2}$ he also states that a fatal case of this occurred one week and a half after a slight attack of scarlet fever. Dr. Collie, in THE LANCET ${ }^{3}$ and in the "Archives of Pediatrics," 4 reports a case of purpura fulminans three weeks after an attack of scarlet fever. Unfortunately, in this case of $\mathrm{J} . \mathrm{O}-\ldots$, it was not possible to trace distinctly the source of infection. There had been a scarlet fever in the ward for some time previously; there was none at his home or in the neighbouring houses. There was, however, an epidemic of small-pox at Warrington which is only a short distance from, and in constant communication with, Ditton, the town in which he lived. This together with the symptoms, and in the light of Dr. Gee's statement, maturally made one suspect hæmorrhagic small-pox. Dr. Gee says: "Scarlatina hæmorrhagica is so rare that the occurrence of a passive hæmorrhage from several mucous membranes at once might make one with justice suspend the diagnosis of scarlet fever until the notion of possibly having to do with variolous roseola was discarded. I have known variola hæmorrhagica to be mistaken for scarlatina hæmorrhagica and the truth not to appear until, in the course of time, those who had dealings with the case were themselves attacked with small-pox." That variola hremorrhagica, however, was rightly discarded would, I think, appear from the following facts : (1) There never was any true small-pox eruption, the child's illness lasting for thirteen clays; (2) the rash was typically that of scarlet fever; (3) desquamation commenced between the seventh and eighth days; (4) no person attending upon the child contracted small-pox.

J, $0-$, aged two years, was admitted into the infirmary on 0ct. 10th, 1892, for the radical cure of an inguinal hernia. He was a fresh-coloured boy and apparently in good health, except for slight bronchitis. His family history was good. There was no history of hæmophilia, and he had had no serious previous illness. On account of the bronchitis the operation was deferred for some ten days. He had one or two occasional rises of temperature in the evening during that time, but for four days before the operation the temperature had been normal. He had eaten and slept well and the motions and urine were normal. On the morning of Oct. 20th the operation, which lasted some thirty minutes, was performed; it presented no special diffisulty. The child had no after-sickness and suffered apparently little from shock. The following morning his temperature was $101^{\circ}$, but except for this feverishness he seemed fairly well. The temperature, however, kept clevated, and on the third day after the operation it was stil nigher $\left(101.4^{\circ} \mathrm{F}\right.$.). He was restless and uneasy. The tongue was coated and furred; the tonsils and fauces were congested the glands at the angle of the jaw were swollen and a diffused punctiform red rash appeared over the upper part of the chest, legs and back. The wound was dressed; itlooked quite healthy and healing. $\mathrm{He}$ was transferred to the fever ward. On the 24 th he romited five times and had diarrhcea. The rash had spread and become much more pronouncerl. The temperature was $1042^{\circ}$; the pulse beat and -evilation were rapid; the urine was highly concentrated, santy and albuminous. On the 29th the urine became

\footnotetext{
1 Disezzes of Children, vol. ii., p. 231.

TII IANCET, March 21 st, 1891 .

2 Vol. ii.,p. 380.
4 July, 1891.
}

intensely bloodstained and much blood was passed per rectum.

This continued till his death, which occurred on Nov. 3rd.

During his illness he developed petechim generally over the body. There were subconjunctival hæmorrhages and bleeding from the gums, nose and stomach, and two large subcutaneous hæmorrhages, one in the right parotid region, the other into the site of the wound. He became very pale, the corpuscles scarcely being 2,000,000 per centimetre, and the proportion of red to white about normal. The urine contained red blood-corpuscles, leucocytes, and epithelial, blood and hyaline casts. Peeling of the skin commenced on the 30 th. The first sound of the heart was replaced by a soft systolic murmur. He had a short, hacking cough and some consolidation towards the apex of the right lung. The retinæ were extremely pale, but no other change was noted on ophthalmoscopic examination. Before death he had a slight convulsion, chiefly left sided.

Necropsy.-The waxy pallor of the body generally contrasted with the hæmorrhages in the situations above described. The right lung was consolidated at the apex (hæmorrhage and pneumonia around it). There was some congestion at both bases. There were several petechiæ under the epicardium, but there was no endocarditis. Numerous hæmorrhages existed under the serous coating of the bowels. The stomach contained altered blood, and many points of hæmorrhage were visible beneath the mucous membrane. Several small ulcers were seen on the sites of older hæmorrhages. The kidneys to the naked eye before section appeared normal, the capsule being non-adherent; but on section the calyces on both sides were filled with blood; both the cortex and medulla were congested. The spleen was congested and there were many hæmorrhages in its substance. There was no hæmorrhage in the membranes, substance or carities of the brain. Beyond the hæmorrhages into the substance of the organs and the congestion and cloudy swelling of the kidneys microscopic examination revealed nothing noteworthy.

\section{Attedical Sorietirs.}

\section{PATHOLOGICAL SOCIETY OF LONDON.}

Melanotic Carcinoma of Skin._-Foreign Body in Hernial Sac.Intra-auricular Cardiac Polypus. - Heart with Congenital Malformations. - Sarcomatous Gronth in CEsophagus associated with Sarcomatous Growths in Bone.-Ner Growth in Descending Colon.-Carcinoma of Lung in a Con.Rupture of Heart.

AN ordinary meeting of this Society was held on Tuesday, Feb. 7th, Sir George M. Humphry, President, in the chair.

Mr. J. Hutohisson, jun., exhibited specimens from two cases of Melanotic Growths of the Skin, demonstrating their nature to be carcinoma and not sarcoma. In one case the tumour commenced in the thigh, in the other the heel. The cells of the malignant growth were arranged in alveolar form, and were distinctly derived from the rete mucosum. In one specimen cell-nests were fairly abundant, and were sometimes deeply pigmented. The cells were, as a rule, much smaller and possessed less distinct outlines than those usually met with in the down growths of skin epithelioma, and it is probable that many of the examples of supposed melanotic sarcoma are really carcinomatous. Sections at the edge of the tumour are necessary to decide the point. Probably melanotic sarcoma and cancer are equally malignant in causing deposits in the lymphatic glands. Allusion was made to the remarkable difference as to this in cases of melanosis, one case being quoted of melanotic sarcoma of the orbit, which, after incomplete removal, continued to discharge black material for six years. At the end of this time the patient was in good health without evidence of secondary deposit.-Dr. NoRMaN MoorE considered Mr. Hutchinson's remarks as to the duration of symptoms important, and adduced two other cases in his own experience in which they had extended over a period of at least three years. He remarked upon the uncertainty as to the exact origin, in relation to the foctal layers, of those cases which commenced in the eye.

Mr. J Hutchinsox, jun., also showed the Sac of a Femoral Hernia, the neck of which was perforated by a strong fish-bone which had eviclently passed through the intestinal wall and through Gimbernat's ligament. The fish-bone had irritated 